\title{
Beta Cell Mass and Growth after Syngeneic Islet Cell Transplantation in Normal and Streptozocin Diabetic C57BL/6 Mice
}

\author{
Eduard Montaña, Susan Bonner-Weir, and Gordon C. Weir \\ Research Division, Joslin Diabetes Center and the Department of Medicine, New England Deaconess Hospital \\ and Brigham and Women's Hospital, Harvard Medical School, Boston, Massachusetts 02215
}

\begin{abstract}
In islet transplantation, nonimmunological factors such as limited growth capacity or increased death rate could reduce the beta cell mass in the graft and lead to failure of the transplant. We studied the evolution of beta cell replication and mass after transplantation of insufficient, minimally sufficient, or excessive islet tissue. Streptozocin diabetic C57BL/6 mice received 150 or 300 syngeneic islets under the kidney capsule and normal mice received 300 islets. In streptozocin diabetic mice 300 islets restored normoglycemia; beta cell replication in transplanted islets was similar to replication in normal pancreas and beta cell mass in the graft remained constant. In contrast, 150 islets were insufficient to achieve normoglycemia; beta cell replication was increased initially but not by 18 or 30 d despite persistent hyperglycemia, and beta cell mass fell progressively. When islets were transplanted into normal recipients, beta cell replication remained normal but beta cells underwent atrophy and mass in the graft was substantially reduced. Therefore, with a successful islet transplant, in diabetic mice beta cell replication and mass remain constant. In contrast, when insufficient islet tissue is transplanted an initial increase in beta cell replication can not compensate for a decline in beta cell mass. When excessive islet tissue is transplanted, beta cell mass is reduced despite normal beta cell replication. (J. Clin. Invest. 1993.91:780-787.) Key words: diabetes • endocrine pancreas • insulin • islet of Langerhans • beta cell replication
\end{abstract}

\section{Introduction}

Transplantation of islet cells was able to restore blood glucose in diabetic rats almost 20 years ago $(1,2)$. However, in diabetic patients the first successful islet transplants were achieved only very recently (3-5). Large numbers of islets must be transplanted into these patients to normalize the blood glucose, well in excess of the $10-30 \%$ of the total beta cell mass that is sufficient to maintain normoglycemia after partial pancreatectomies (6-8). The reasons for the need of such a large amount of islet tissue are not well known. The early and late failures of islet autotransplants in animal models suggest that the immu-

A preliminary report of this work was presented at the XXVII Meeting of the European Association for the Study of Diabetes, 9-14 September 1991, Dublin, Republic of Ireland.

Address correspondence to Eduard Montaña, Research Division, Joslin Diabetes Center, One Joslin Place, Boston, MA 02215.

Received for publication 14 April 1992 and in revised form 15 September 1992.

J. Clin. Invest.

(C) The American Society for Clinical Investigation, Inc.

0021-9738/93/03/0780/08 \$2.00

Volume 91, March 1993, 780-787 nological factors alone can not explain the poor results (9). Loss of islets during the transplantation, lack of engraftment, anoxia, and islet death in the first days could, among other causes, decrease the effective beta cell mass and contribute to the early failure of the graft. A toxic effect of immunosuppressive treatment on beta cell function can also be invoked ( 10 , 11). The mass of transplanted islets seems to play a critical role in the outcome of the graft. A critical amount of islet tissue must be transplanted to achieve normoglycemia and late failures have been shown to depend on the number of initially transplanted islets (12-14). Either a limitation in the growth capacity of transplanted islets compared to endogenous pancreatic islets, or an increased death rate overwhelming the growth capacity could lead to continuous loss of beta cell mass and failure of the graft. Such factors could help explain the discrepancies between the long-term success of whole pancreas transplantation and the limited survival of islet transplantations in large animals and in humans $(3,10,15)$. However, little is known about the growth capacity and fate of transplanted beta cells and the factors that modify such events. Thus, we studied the evolution of beta cell replication and mass after transplantation of differing quantities of islet tissue that were insuffcient, minimally sufficient, or excessive, three different situations that might be found in clinical transplantation.

\section{Methods}

\section{Animals}

Male inbred C57BL/ 6 mice, aged 10 to $14 \mathrm{wk}$, were used as donors and recipients of the transplantation. The recipients were made diabetic by a single intraperitoneal injection of streptozocin (Streptozotocin, Sigma Immunochemicals, St. Louis, MO) $200 \mathrm{mg} / \mathrm{kg}$ body wt, freshly dissolved in citrate buffer $(\mathrm{pH}=4.5)$. Before transplantation, diabetes was confirmed by the presence of hyperglycemia, weight loss, and polyuria. Only those mice with a blood glucose higher than $20 \mathrm{mmol} /$ liter were transplanted. On days $2,4,6,10,18$, and 30 after transplantation blood glucose was determined between 9 and 11 a.m. Blood was obtained from the snipped tail with a heparinized microcapillary tube and glucose was measured with a portable glucose meter (Accu-Check II; Boehringer-Mannheim Biochemicals, Indianapolis, IN). Body weight was measured on the same days. The animals were kept under conventional conditions in climatized rooms with free access to tap water and standard pelleted food.

\section{Animal groups}

Eight groups of transplanted animals (Table I) were studied: ( $a$ ) streptozocin diabetic mice transplanted with 300 islets that had the grafts removed after $10 \mathrm{~d}$ (group $1, n=6$ ), $18 \mathrm{~d}$ (group $2, n=4$ ), or $30 \mathrm{~d}$ (group 3, $n=5$ ); (b) streptozocin diabetic mice transplanted with 150 islets that had the grafts removed after $10 \mathrm{~d}$ (group 4, $n=6$ ), $18 \mathrm{~d}$ (group 5, $n=6$ ), or $30 \mathrm{~d}$ (group 6, $n=6$ ); (c) normoglycemic mice (previously injected with citrate buffer alone) transplanted with 300 islets that had both the grafts and the endogenous pancreases removed after 10 (group 7, $n=11$ ) or $30 \mathrm{~d}$ (group $8, n=11$ ). In these two last 
groups six animals were studied for beta cell replication and beta cell mass, and the remaining five for insulin content. The rationale for the number of islets transplanted was that 300 islets is the minimum amount that can always restore normoglycemia in diabetic C57B1/6 mice, while a transplant of 150 islets does not achieve normoglycemia $(16,17)$. Therefore, we had a model of successful transplantation with a minimum amount of beta cell mass and a model of unsuccessful transplantation due to an insufficient beta cell mass. In addition an excessive beta cell mass was obtained by transplantation in the normal recipients.

Three control groups of nontransplanted animals were studied. A group of streptozocin diabetic mice $(n=9)$ had their blood glucose and body weight checked at the same time points as the transplanted mice. Two groups of normal mice of similar body weight as group $7(n=11)$ and as group $8(n=11)$ were killed to determine the pancreatic beta cell mass $(n=6)$ and insulin content $(n=5)$. Finally the beta cell mass of $300(n=9)$ and 150 isolated islets $(n=7)$, as well as the insulin content of 300 isolated islets $(n=5)$, were determined.

\section{Islet isolation and transplantation}

Under anesthesia with sodium amobarbital (Amytal ${ }^{\circledR}$ sodium; Eli Lilly \& Co., Indianapolis, IN) $200 \mathrm{mg} / \mathrm{kg}$ intraperitoneally, a laparotomy was performed and the pancreas was exposed. The common bile duct was ligated at the ampulla of Vater, cannulated proximally with a 27 gauge needle, and injected with $2 \mathrm{ml}$ of a solution containing $2 \mathrm{mg}$ of collagenase (collagenase from Clostridium histoliticum; Serva, Heidelberg, Germany) per ml of M-199 medium (GIBCO BRL, Gaithersburg, MD) with $26 \mathrm{mM} \mathrm{NaHCO}$. The animal was killed and the pancreas dissected from surrounding tissues, removed, and incubated in a stationary bath for $22-26 \mathrm{~min}$ at $37^{\circ} \mathrm{C}$. After incubation the digested tissue was washed three times with M-199 media with $26 \mathrm{mM}$ $\mathrm{NaHCO}_{3}$ and $10 \%$ heat inactivated newborn calf serum (GIBCO $\mathrm{BRL}$ ), and filtered through a collector tissue sieve (40 mesh; Fisher Scientific, Pittsburgh, PA). The islets were separated by a density gradient (Histopaque-1077; Sigma Immunochemicals) centrifuged at $2,500 \mathrm{rpm}$ for $20 \mathrm{~min}(18)$. Isolated islets were recovered from the gradient interface, washed three times with the same media, placed in a $60 \times 15-\mathrm{mm}$ plastic petri dish (Fisher Scientific), and hand-picked under a stereomicroscope two or three times until a population of pure islets was obtained. Islets $>75$ and $<250 \mu \mathrm{m}$ in diameter were collected and carefully counted into groups of 300 and 150 islets. Islets with ragged edges suggesting overdigestion were not used. With these restrictions the final yield was $120-150$ islets per pancreas.

The islets were transplanted under the kidney capsule of the recipients on the same day of the isolation. The islets were centrifugated in a 200- $\mu$ l pipette tip (USA Scientific Plastics, Ocala, FL) previously plugged with Gelfoam ${ }^{\circledast}$ (The Upjohn Co., Kalamazoo, MI). With the mouse under light ether anesthesia, the left kidney was exposed through a lumbar incision. A capsulotomy was performed in the lower kidney pole and the islets injected under the kidney capsule of the upper pole through the pipette tip. The capsulotomy was left unsutured.

\section{Graft and pancreas removal}

On the day of graft removal the mice were injected with 5-bromo$2^{\prime}$ deoxyuridine (BrdU) ${ }^{1}$ (Sigma Immunochemicals), $100 \mathrm{mg} / \mathrm{kg}$ body $w t$ intraperitoneally, and $6 \mathrm{~h}$ later the graft was removed. With the mouse under light ether anesthesia the left kidney was exposed and the graft identified as a white patch. The kidney capsule surrounding the graft was incised and removed with the graft. Usually all the graft was removed with the capsule; in the few cases where the grafted islets were infiltrating the kidney cortex a second piece of tissue was also taken to ensure that the entire graft was taken. A left nephrectomy was subsequently performed in groups 1-6 and the blood glucose level and body weight determined on the following days. All normoglycemic mice (groups 1-3) returned to hyperglycemia after graft excision and in al-

1. Abbreviation used in this paper: BrdU, 5-bromo-2'deoxyuridine. ready hyperglycemic mice (groups 4-6) blood glucose values increased and body weight decreased. In groups 7 and 8 the animals were killed after the graft recovery and the pancreas was excised, blotted, weighed, and fixed in Bouin's solution. Subsequently, the pancreas was embedded in paraffin.

\section{Immunocytochemistry}

After removal, the graft was immediately immersed in a preweighed drop of Bouin's fixative. The weight of the graft was determined by reweighing on a balance reading to $0.05 \mathrm{mg}$ ( type $\mathrm{H} 16$; Mettler Instruments Corp., NJ). The graft was processed for plastic embedding ( Araldite, Ernest F. Fullan, Inc., Latham, NY). $1 \mu \mathrm{m}$ sections were affixed to glass by heat; the plastic resin was removed with sodium metoxide. To assess the beta cell replication the sections were double stained for BrdU and for the endocrine non-beta cells of the islets with immunoperoxidase. BrdU is a thymidine analogue that is incorporated into newly synthesized DNA of cells in the S phase of the cell cycle (19). Immunostaining for BrdU used a Cell Proliferation Kit (Amersham International, Amersham, UK). The sections were incubated with a mouse monoclonal antibody anti-BrdU in a solution containing nuclease for DNA denaturation for $48 \mathrm{~h}$ at $4^{\circ} \mathrm{C}$, washed with PBS ( $\mathrm{pH}$ $=7.4$ ), incubated with an affinity-purified peroxidase anti-mouse Ig, and stained with 3,3'-diaminobenzidine tetrahydrochloride plus a substrate/intensifier containing hydrogen peroxide and nickel chloride/ cobalt chloride. The sections were then washed with $0.01 \mathrm{mM} \mathrm{HCl}$ and with tap water, soaked in PBS plus $1 \%$ lamb serum (GIBCO BRL), and subsequently stained for the endocrine non-beta cells. The primary antibody was a cocktail of antibodies: rabbit anti-bovine glucagon (final dilution 1:3,000, gift of Dr. M. Appel, Cytotheraputics, Inc., Providence, RI), rabbit anti-synthetic somatostatin, final dilution 1:300, made in our own laboratory), and rabbit anti-bovine pancreatic polypeptide, 1:3,000 final dilution, gift of Dr. R. Chance, Eli Lilly \& Co.). The sections were incubated with this cocktail for $48 \mathrm{~h}$ at $4^{\circ} \mathrm{C}$, washed with PBS, incubated with a goat anti-rabbit IgG as secondary antibody, washed with Tris-chloride $(\mathrm{pH}=7.4)$, incubated with a peroxidase anti-rabbit serum (Cappel Laboratories, Cochranville, PA) and stained with 3,3'-diaminobenzidine tetrahydrochloride (Sigma Immunochemicals) and hydrogen peroxide (Fisher Scientific).

\section{Beta cell replication}

On the stained sections the islet tissue was easily identified on the light microscope level (Fig. 1): the endocrine non-beta cells with an orangebrown cytosol, and the beta cells with a nonstained cytosol. BrdU positive staining was seen as blue/black nuclei. Using an Olympus BH-2 microscope connected to a video camera with a black and white monitor at a final magnification of 760, beta cells and BrdU-positive beta cells were counted; results were expressed as the percentage of BrdUpositive beta cells. We stained the endocrine non-beta cells instead of the beta cells because cells with stained cytosol and nucleus are difficult to discern and also because chronic hyperglycemia, which is associated with beta cell degranulation resulting in a weak or negative staining of beta cells, was expected in groups 4-6. At least 1,200 cells were counted per graft; all the endocrine cells in a section were counted, and when needed, a second section was included. A similar procedure was used to stain the paraffin-embedded pancreatic sections. The sections were systematically sampled, counting cells until a minimum of 1,200 endocrine cells per pancreas was scored for BrdU.

\section{Beta cell mass}

Beta cell mass was measured by point counting morphometry on immunoperoxidase-stained sections of graft and endogenous pancreas. For the graft tissue each section was covered systematically at a magnification of 760 using a 48-point grid to obtain the number of intercepts over beta cells, over endocrine non-beta cells, and over other tissue. The beta cell relative volume was calculated by dividing the intercepts over beta cells by intercepts over total tissue; then the beta cell mass was estimated by multiplying beta cell relative volume by graft weight. A nomogram relating number of points counted to volume density and 

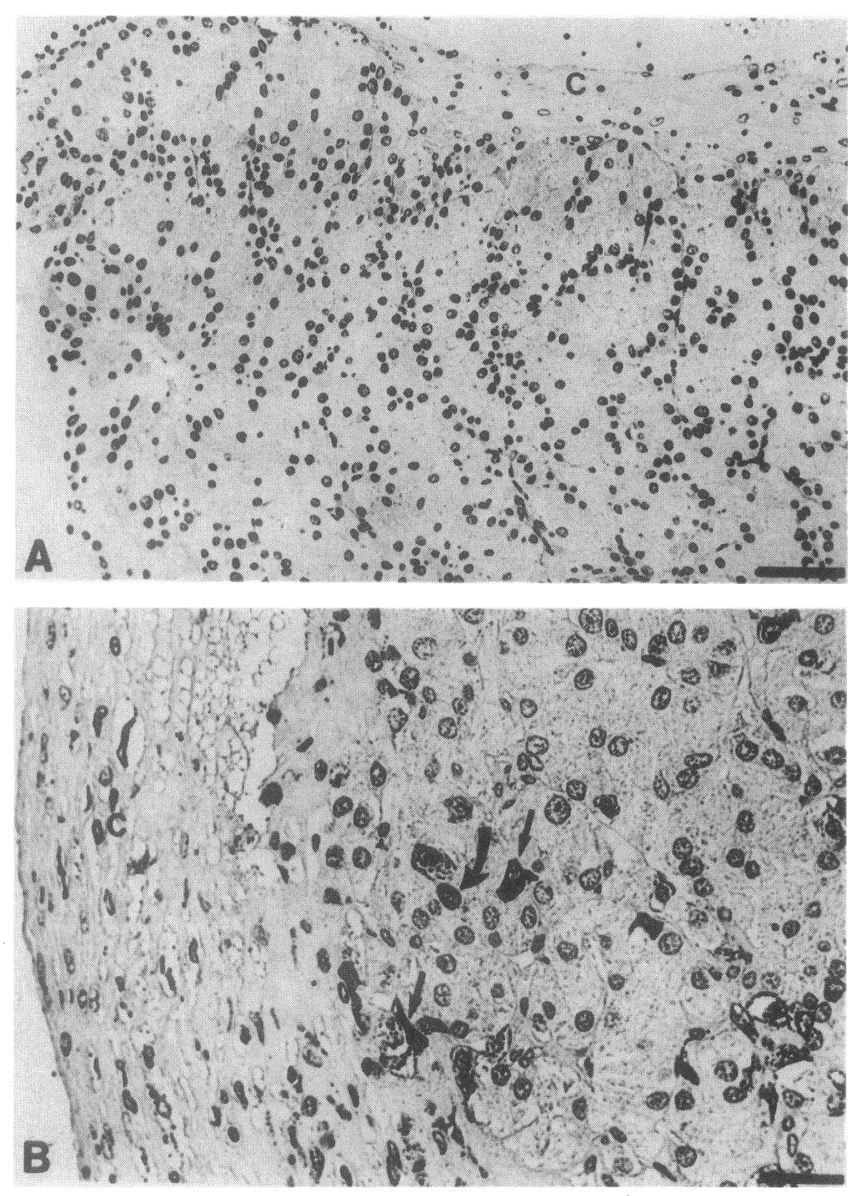

Figure 1. Micrograph showing transplanted islet tissue. $(A)$ At low magnification the well preserved islet tissue is easily distinguished under the kidney capsule $(c)$. Semi-thin $(1 \mu \mathrm{m})$ section stained with methylene blue. Magnification bar $=25 \mu \mathrm{m}$. (B) At higher magnification showing double immunostained islet tissue transplanted under kidney capsule $(c)$. Cytoplasmic staining for noninsulin islet hormones identifies endocrine non-beta cells (arrow). Replicating beta cell (curved arrow) is identified by BrdU-positive nucleus, endocrine cell morphology and lack of cytoplasmic staining. Color differences (blue-black BrdU-positive nucleus, orange-brown islet hormone-positive cytoplasm) enhanced the visual recognition of the labeled cells on the sections. Immunoperoxidase stained $1 \mu \mathrm{m}$ section, hematoxylin counterstained. Magnification bar $=100 \mu \mathrm{m}$.

expected relative standard error in percentage of mean $(<10 \%)$ had been used to determine the number of intercepts needed for a representative sampling (20). The beta cell mass of the pancreas was assessed similarly.

To determine the beta cell mass of the islets at the time of the transplantation, eight groups of 300 islets and nine groups of 150 islets isolated on five different days were washed in PBS after isolation and pelleted in Bouin's fixative. Any excess of Bouin's was removed by capillary action and the pellet was immersed in a preweighed drop of Bouin's that was reweighed to obtain the weight of the islet pellet. Beta cell mass was obtained by multiplying the weight of the islets by the percentage of beta cell volume as derived from our data $(91.6 \%)$. To determine the accuracy of these measurements, 50 islets from each of three different isolations were measured for individual islet diameter and volume. To do this, islets were photographed on an inverted phase microscope. Islet perimeter was measured on the photographs using an electronic planimetry program (Sigma Scan; Jandel Scientific, Corte Madera, CA). For calculations islets were assumed to be spheres, and the individual and mean islet diameters and volumes were calculated.

\section{Beta cell area}

The mean cross-sectional area of individual beta cells, a measure of beta cell size, was determined on immunoperoxidase-stained sections of grafts and isolated islets. The area of beta cells from all grafts was measured on the same sections on which beta cell mass and replication were determined. The area of beta cells on the day of transplantation was determined on sections from the same pellets of 150 and 300 isolated islets used to measure the initially transplanted beta cell mass. The pellets had been embedded in plastic (Araldite) and $1-\mu \mathrm{m}$ sections stained by immunoperoxidase as described before for the graft samples. 10 pellets from three different isolations were used. For both grafts and isolated islets the beta cell nuclei on a random field were counted (70130 nuclei). The perimeter of the beta cell tissue in that field was carefully traced, to exclude any other tissue, on an acetate sheet overlaid on the monitor, and the beta cell area was then measured with an electronic planimetry program (Sigma Scan; Jandel Scientific). The beta cell area was divided by the number of beta cell nuclei in the field to calculate the area of the individual beta cells. The actual number of beta cells in the field was in fact higher than the number counted, since not all beta cells were sectioned across their nuclei and, therefore, the size of the beta cells was overestimated.

\section{Insulin content}

The grafts were removed from the kidney as described above, then minced and sonicated in acid ethanol. The pancreases were removed, blotted, weighed, and then stored in acid ethanol at $-20^{\circ} \mathrm{C}$. Later they were homogenized using an Ultra Turrax SDT (Tekmar Co., Cincinnati, $\mathrm{OH})$. Five groups of 300 islets were sonicated in acid ethanol after isolation. After sonication or homogenization the samples were extracted overnight at $4^{\circ} \mathrm{C}$. On the following day they were centrifuged at $2,400 \mathrm{rpm}$ for $10 \mathrm{~min}$ and the supernatant was stored at $-20^{\circ} \mathrm{C}$. The pellet was again sonicated or homogenized in acid ethanol and insulin extracted overnight. After centrifugation this second supernatant was added to the first extraction sample. Insulin was measured by radioimmunoassay with charcoal separation (21).

\section{Statistical analysis}

Results were expressed as mean and standard error of the mean $(\mathrm{X} \pm \mathrm{SEM})$. For comparisons between two groups the paired or the unpaired Student's $t$ test (two tailed) were used as appropriate. For multiple comparisons the one-way ANOVA was used. A $P$ value of $<0.05$ was considered significant.

\section{Results}

Metabolic evolution after transplantation (Table I). All animals were comparable in age and body weight when injected with streptozocin or citrate buffer at the start of the experiments (data not shown). At the time of the transplantation the six groups of streptozocin diabetic animals had similar blood glucose values and body weight, and the same was true for the two groups of nondiabetic animals. Initially, the diabetic animals that were not transplanted had blood glucose values and body weights not different than those of the streptozocin animals that were transplanted. This nontransplanted group had continuous clinical deterioration with persistent severe hyperglycemia and weight loss, and after $30 \mathrm{~d}$ of follow-up $45 \%$ of these mice had died. In contrast, all transplanted animals showed clinical improvement. The recipients of 300 islets were restored to normoglycemia after transplantation. By day 10 their mean blood glucose value was in the normal range, although when compared with initially normoglycemic recipients it was still significantly elevated. By day 18 or 30 there were no differences between the blood glucose values of initially diabetic and normoglycemic recipients of 300 islets. 


\begin{tabular}{|c|c|c|c|c|c|c|c|}
\hline \multirow[b]{2}{*}{ Group } & \multirow[b]{2}{*}{$\mathrm{STZ}^{*}$} & \multirow[b]{2}{*}{$\begin{array}{c}\text { Islets } \\
\text { number }\end{array}$} & \multirow[b]{2}{*}{$\begin{array}{l}\text { Days of } \\
\text { transplant }\end{array}$} & \multicolumn{2}{|c|}{ Day transplant } & \multicolumn{2}{|c|}{ Day graft removal } \\
\hline & & & & Glucose & $\begin{array}{c}\text { Body } \\
\text { weight }\end{array}$ & Glucose & $\begin{array}{l}\text { Body } \\
\text { weight }\end{array}$ \\
\hline & & & & $m M / l i t e r$ & $g$ & $m M / l i t e r$ & $g$ \\
\hline $1(n=6)$ & + & 300 & 10 & $23.5 \pm 0.5^{\ddagger}$ & $23.4 \pm 1.1^{\ddagger}$ & $8.8 \pm 0.4^{\S}$ & $25.1 \pm 0.8$ \\
\hline $2(n=4)$ & + & 300 & 18 & $24.8 \pm 0.9^{\ddagger}$ & $23.0 \pm 1.2^{\ddagger}$ & $7.5 \pm 0.4$ & $25.5 \pm 0.8$ \\
\hline $3(n=5)$ & + & 300 & 30 & $24.0 \pm 1.0^{\ddagger}$ & $23.4 \pm 1.0^{\ddagger}$ & $8.1 \pm 0.4$ & $26.6 \pm 0.8$ \\
\hline $4(n=6)$ & + & 150 & 10 & $25.4 \pm 0.5^{\ddagger}$ & $21.9 \pm 0.4^{\ddagger}$ & $22.5 \pm 1.2$ & $24.0 \pm 0.5$ \\
\hline $5(n=6)$ & + & 150 & 18 & $23.8 \pm 0.6^{\ddagger}$ & $20.9 \pm 0.5^{\ddagger}$ & $19.3 \pm 3.2$ & $23.7 \pm 0.4$ \\
\hline $6(n=6)$ & + & 150 & 30 & $24.8 \pm 0.6^{\ddagger}$ & $22.1 \pm 0.5^{\ddagger}$ & $21.6 \pm 2.4$ & $25.5 \pm 0.4$ \\
\hline $7(n=11)$ & - & 300 & 10 & $7.0 \pm 0.2$ & $26.9 \pm 0.4$ & $7.5 \pm 0.2$ & $26.4 \pm 0.5$ \\
\hline $8(n=11)$ & - & 300 & 30 & $7.4 \pm 0.2$ & $26.9 \pm 0.4^{\ddagger}$ & $7.1 \pm 0.1$ & $29.4 \pm 0.9$ \\
\hline $9(n=9)^{\|}$ & + & \multicolumn{2}{|c|}{ Nontransplanted } & $23.6 \pm 0.8$ & $22.2 \pm 0.5$ & $25.8 \pm 1.0$ & $20.7 \pm 0.7$ \\
\hline
\end{tabular}

* STZ, streptozocin-induced diabetes. ${ }^{\ddagger} P<0.001$ compared to day of graft removal. ${ }^{\S} P=0.01$ compared to group 7 . "Group 9 , nontransplanted streptozocin diabetic mice; in this group day transplant columns show blood glucose values and body weights $7 \mathrm{~d}$ after streptozocin injection, and day graft removal columns show the values $30 \mathrm{~d}$ later. Values are mean \pm SEM.

When only 150 islets were transplanted all recipients but one remained severely hyperglycemic. Even so, at the time of graft removal blood glucose values were lower than at transplantation and the body weights had increased.

The normoglycemic recipients of 300 islets showed no significant change in blood glucose values after transplantation. Their body weight was not increased by day 10 , possibly due to some loss associated with the surgical procedure, but thereafter their weight gain was similar to normal animals.

Beta cell replication (Fig. 2). The diabetic mice in which normoglycemia was restored with transplantation of 300 islets (groups 1-3) had a beta cell replication similar to that of beta cells in the normal pancreas. However, when the 10-d group (group 1) was analyzed independently of the groups at 18 and $30 \mathrm{~d}$ (groups 2 and 3 ) its graft beta cell replication was significantly higher than in normal pancreas $(1.03 \pm 0.19 \%$ vs $0.49 \pm 0.06 \%, P<0.05$ ). As already described the blood glucose of this group was slightly elevated. When hyperglycemia per-

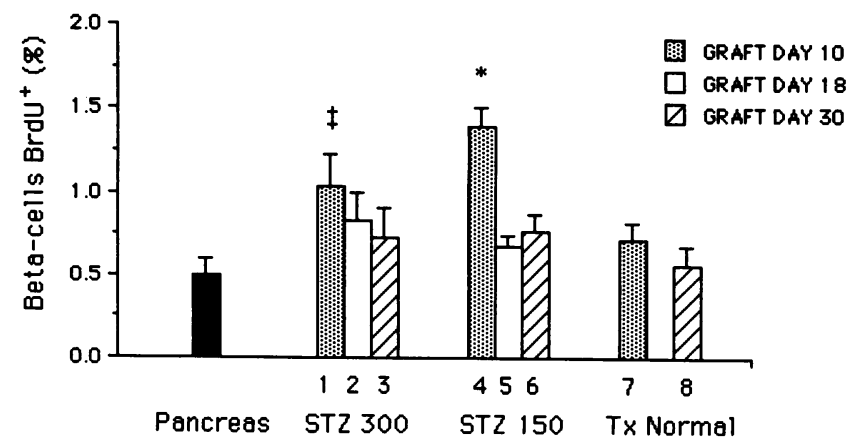

Figure 2. Beta cell replication in normal pancreas and in transplanted islets. Replication is expressed as percentage of BrdU positive beta cells. (STZ 300) Streptozocin diabetic mice transplanted with 300 islets. (STZ 150) Streptozocin diabetic mice transplanted with 150 islets ( Tx normal) Normal mice transplanted with 300 islets. Numbers on the $x$ axis correspond to transplanted groups shown in Table I. Values are mean \pm SEM. ${ }^{*} P<0.05$ between group 4 and all other groups with the exception of group $1 ;{ }^{\ddagger} P<0.05$ between group 1 and normal pancreas. sisted after transplantation (groups 4-6), beta cell replication was increased. When groups were analyzed individually, only group 4 (studied $10 \mathrm{~d}$ after transplantation) had a beta cell replication significantly increased compared to normal pancreatic beta cells or to the transplanted islets under strict normoglycemic conditions (group 4: $1.39 \pm 0.11 \%, P<0.05$ vs groups 2 , 3,7 , and 8). After $18 \mathrm{~d}$ (group 5: $0.68 \pm 0.06 \%$ ) and $30 \mathrm{~d}$ (group 6: $0.72 \pm 0.11 \%$ ) of hyperglycemia, transplanted islets no longer maintained the increased beta cell replication found at day 10 $(P<0.01$ vs group 4$)$. Islets transplanted into normoglycemic recipients had a beta cell replication similar to that of pancreatic islets of normal animals, both at day 10 (group 7: $0.71 \pm 0.11 \%$ ) and at day 30 (group 8: $0.56 \pm 0.11 \%$ ). The pancreatic beta cell replication of these nondiabetic transplanted mice was also comparable after $10 \mathrm{~d}$ (group 7: 0.48 $\pm 0.11 \%$ ) and $30 \mathrm{~d}$ (group 8: $0.57 \pm 0.07 \%$ ).

Beta cell mass. The beta cell mass measured in groups of 150 and 300 isolated islets was $0.46 \pm 0.06 \mathrm{mg}$ and $0.89 \pm 0.09$ $\mathrm{mg}$, respectively. The beta cell mass calculated from the measurements of individual islet size was $0.51 \pm 0.6 \mathrm{mg}$ and $1.02 \pm 0.10 \mathrm{mg}$, respectively, confirming the accuracy of the values based on the weight of the samples. Therefore, the values obtained from the groups of isolated islets were used for comparison with the beta cell mass in the grafts. When 300 islets were transplanted into streptozocin diabetic recipients and normoglycemia was restored, the beta cell mass recovered from the grafts after $10 \mathrm{~d}$ (group 1: $0.91 \pm 0.33 \mathrm{mg}$ ) or $30 \mathrm{~d}$ (group 3: $0.64 \pm 0.09 \mathrm{mg}$ ) was similar to the beta cell mass originally transplanted (Fig. 3). On the other hand, when an insufficient number of islets was transplanted, beta cell mass was reduced by day 10 (group $4: 0.31 \pm 0.07 \mathrm{mg}$ ) with a further reduction being found after $30 \mathrm{~d}$ (group 6: $0.17 \pm 0.03 \mathrm{mg}$ ) of hyperglyce$\operatorname{mia}(P<0.001)$.

The beta cell mass transplanted into normal recipients was significantly reduced at day 10 (group 7:0.17 $\pm 0.03 \mathrm{mg}$ ) and at day 30 (group 8: $0.40 \pm 0.12 \mathrm{mg})(P<0.001)$, although it tended to recover partially at day $30(P=0.097$ vs day 10$)$ (Fig. $4 A$ ). The beta cell mass of the endogenous pancreas was comparable to that of normal nontransplanted mice matched for body weight (Fig. $5 \mathrm{~A}$ ). 


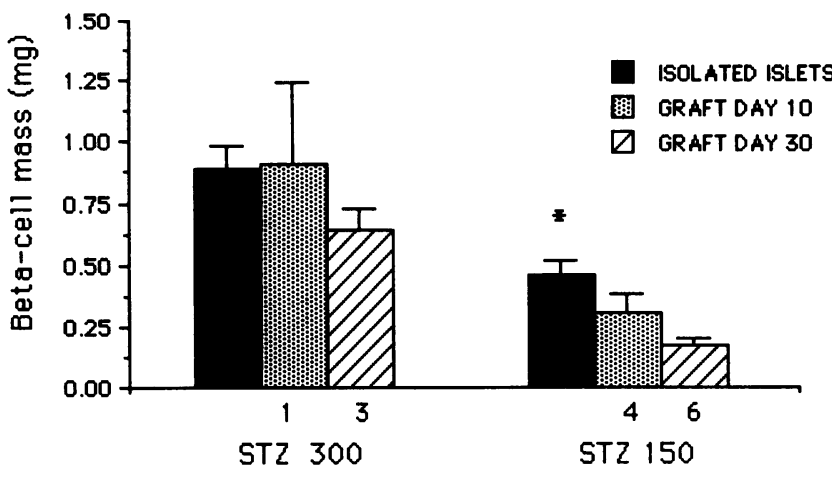

Figure 3. Beta cell mass after transplantation into streptozocin diabetic mice. ( $S T Z 300$ ) Beta cell mass of 300 isolated islets and of grafts of 300 islets. (STZ 150) Beta cell mass of 150 isolated islets and of grafts of 150 islets. Numbers on the $x$ axis correspond to transplanted groups shown in Table I. Values are mean \pm SEM. ${ }^{*} P<0.001$ between 150 isolated islets, graft at day 10 (group 4), and graft at day 30 (group 6).

Beta cell area (Fig. 6). The individual area of beta cells in isolated islets was $271 \pm 14 \mu \mathrm{m}^{2}$. This value was higher than what had been previously described for normal beta cells (2224), but as mentioned above, we expected an overestimation of cell area with our method. However, since all samples were processed and measured exactly in the same way, differences

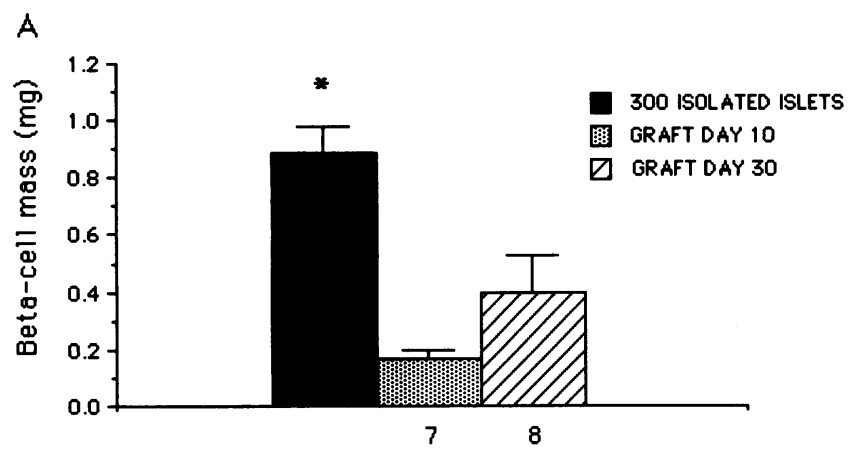

B

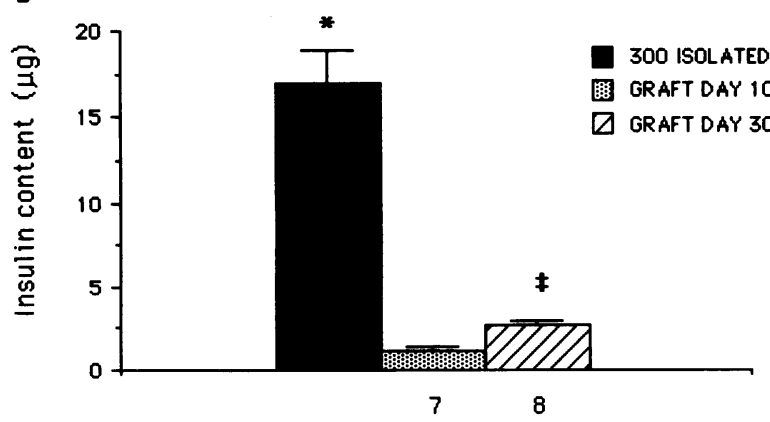

Figure 4. Graft beta cell mass and insulin content after transplantation into normal mice. Numbers on the $x$ axis correspond to transplanted groups shown in Table I. Values are mean \pm SEM. $(A)$ Beta cell mass of 300 isolated islets and of grafts of 300 islets. ${ }^{*} P<0.001$ between 300 islets after isolation, graft at day 10 (group 7), and graft at day 30 (group 8 ) . ( $B$ ) Insulin content of 300 isolated islets and of grafts of 300 islets. ${ }^{*} P<0.001$ between 300 islets after isolation, graft at day 10 (group 7 ), and graft at day 30 (group 8 ). ${ }^{\ddagger} P<0.01$ between day 10 and day 30 grafts.
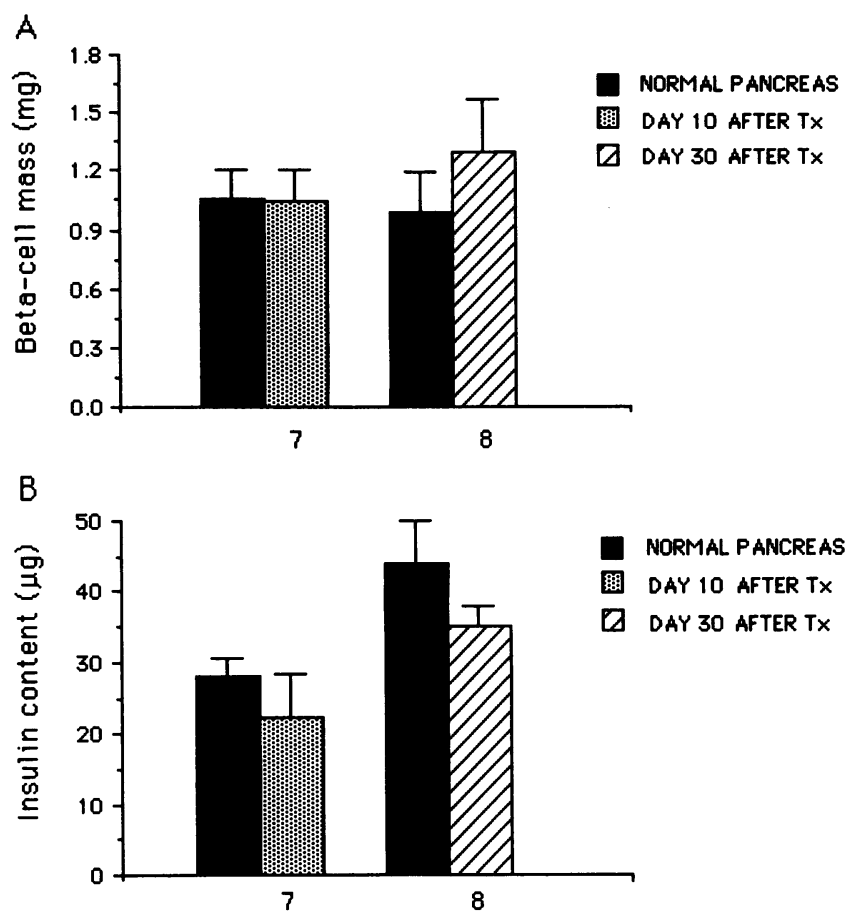

Figure 5. Pancreatic beta cell mass and insulin content of normal nontransplanted mice and of nondiabetic transplanted mice. Numbers on the $x$ axis correspond to transplanted groups shown in Table I. Normal and transplanted groups were matched for body weight. Values are mean \pm SEM. $(A)$ Pancreatic beta cell mass of normal nontransplanted mice and of mice after transplantation of 300 islets. (B) Pancreatic insulin content of normal nontransplanted mice and of mice after transplantation of 300 islets.

between groups reflected real changes in beta cell size. Beta cells transplanted into diabetic recipients in which normoglycemia was restored showed an increased area at day 30 after transplantation (group 3: $305 \pm 13 \mu \mathrm{m}^{2}$ ) when compared to any other transplanted group $(P<0.01)$. In contrast, islets transplanted into normal animals showed a significant reduction in the area of beta cells $10 \mathrm{~d}$ after transplantation (group 7: $\left.217 \pm 15 \mu \mathrm{m}^{2}\right)$ compared to the beta cell area on the day of transplantation $(P<0.05)$.

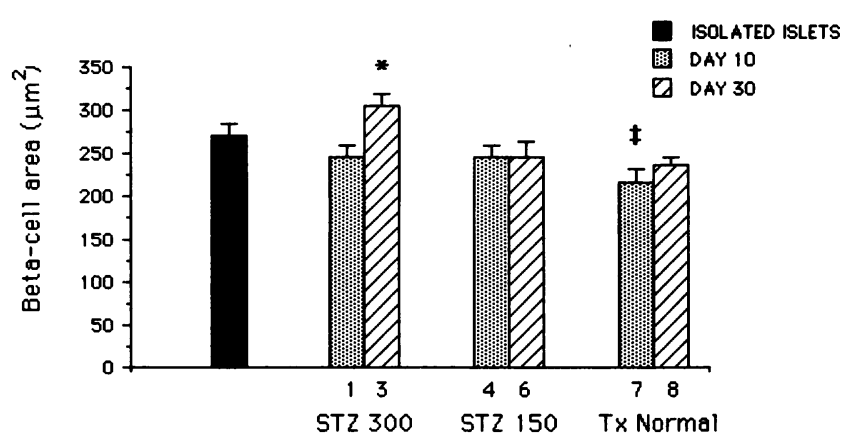

Figure 6. Area of individual beta cells from isolated and transplanted islets. (STZ 300) Streptozocin diabetic mice transplanted with 300 islets. (STZ 150) Streptozocin diabetic mice transplanted with 150 islets. ( Tx normal) Normal mice transplanted with 300 islets. Numbers on the $x$ axis correspond to transplanted groups shown in Table I. Values are mean \pm SEM. ${ }^{*} P<0.01$ between group 3 and all other transplanted groups. ${ }^{\ddagger} P<0.05$ between group 7 and isolated islets. 
Insulin content. The insulin content of grafts and endogenous pancreas from normal mice transplanted with 300 islets (groups 7 and 8 ) reflected the beta cell mass measurements. These values were compared with the insulin content of 300 freshly isolated islets $(16.2 \pm 2.0 \mu \mathrm{g})$ and of pancreas of normal nontransplanted animals matched for body weight. There was a significant reduction in the insulin content of the grafts at day 10 (group 7: $1.10 \pm 0.35 \mu \mathrm{g}$ ) and at day 30 (group 8: 2.65 \pm 0.19 $\mu \mathrm{g})(P<0.001)$ compared with 300 isolated islets, the $30-\mathrm{d}$ value being significantly higher than that at $10 \mathrm{~d}(P<0.01)$ (Fig. $4 B$ ). No differences were found between the insulin content of the pancreas of transplanted and of control animals matched for body weight (Fig. $5 \mathrm{~B}$ ).

\section{Discussion}

We have studied the replicative capacity of transplanted beta cells and the evolution of beta cell mass over the first month after transplantation in models that reproduce three different situations in islet transplantation: $(a)$ transplantation of the minimum amount of beta cell mass necessary to restore normoglycemia; $(b)$ transplantation of a beta cell mass insufficient to restore normoglycemia; $(c)$ transplantation of an excess of beta cells. When a sufficient beta cell mass was transplanted, replication of beta cells was normal and the graft beta cell mass remained unchanged. In contrast, if an insufficient beta cell mass was transplanted, a limitation in beta cell replication was found and the graft beta cell mass declined progressively. Finally, when an excessive beta cell mass was transplanted, the graft beta cell mass diminished despite a normal replication.

When normoglycemia was restored by transplantation, the replication of transplanted beta cells was similar to that of pancreatic beta cells of normal animals. Beta cell replication was determined by $\mathrm{BrdU}$ incorporation in cells in the $\mathrm{S}$ phase of the cell cycle; this incorporation has been validated as an indicator of proliferation in vivo (19) and represents a safer and more rapid alternative to classic autoradiography with $\left[{ }^{3} \mathrm{H}\right]-$ thymidine. By double staining for BrdU and endocrine nonbeta cells we specifically assessed the replication of beta cells instead of the total islet cell replication analyzed in previous studies (25-30). Since the $\mathrm{G}_{2}$ phase and $\mathrm{M}$ phase of beta cells have been estimated to be $5.5 \mathrm{~h}$ and $0.5 \mathrm{~h}$, respectively (31), the 6-h labeling period allowed BrdU incorporation into the DNA without division of labeled cells. Indeed, we identified occasional mitotic figures, but we were unable to find doublets of BrdU-positive beta cells that would suggest the presence of labeled daughter cells. The beta cell replication rate in these normoglycemic animals agrees with our previous in vivo studies with young rats, in which $\sim 0.5 \%$ of B cells had mitotic figures $4 \mathrm{~h}$ after treatment with colchicine (32). Our incorporation of BrdU after a 6-h exposure would correspond to a cell birth rate of 2-3\% per $24 \mathrm{~h}$, similar to other studies in adult rodents (31-33). Beta cell replication was, however, increased at day 10 after transplantation. At this time point the mean blood glucose was still modestly, but significantly, elevated. Since glucose is a known stimulus for beta cell replication, that elevation was probably an important contributor to the increased beta cell replication.

When islet transplantation was sufficient to restore normoglycemia, the beta cell mass of the graft on days 10 and 30 was similar to the originally transplanted beta cell mass, and on day 30 the grafted beta cells had an increased size compared to all other transplanted groups. Pancreatic islets are a highly vascularized tissue and in the first days after transplantation they are probably hypoxic. Islets in culture develop central necrotic cores suggesting cell death due to anoxia, and the fraction of the islet core that becomes necrotic correlates with the islet size (34). Therefore, although we carefully selected the islets with a diameter below $250 \mu \mathrm{m}$ for transplantation, we still expected some degree of beta cell death due to hypoxia during the first days. The transplantation procedure probably is associated with some additional beta cell loss. Therefore the similarity between transplanted and recovered beta cell mass by day 10 in the successful transplantation model suggests that beta cell replication was able to compensate for any beta cell loss. By day 30 the increase in beta cell size also played a role in preserving the total beta cell mass. The hypertrophy of these cells may reflect the increased metabolic demand placed upon them to maintain normoglycemia in the recipient $(24,35,36)$.

When an insufficient islet tissue was transplanted, an initial increase in replication was found after $10 \mathrm{~d}$ of hyperglycemia. The two- to threefold stimulation of beta cell growth was probably driven by hyperglycemia and is similar to that reported in the presence of high glucose levels in both in vivo and in vitro conditions $(31,37)$. However, after 18 and $30 \mathrm{~d}$ of severe hyperglycemia, this increased replication was not maintained, indicating a limitation for growth capacity of transplanted beta cells. The mechanisms underlying this limitation are unknown. It cannot be caused by impaired access of BrdU to transplanted islets, since by $10 \mathrm{~d}$ after syngeneic transplantation the glomerular-like microvascular network of islets is restored (38), and transplanted islets seem to be fully vascularized by day $14(39,40)$. The presence of hyperglycemia could diminish the blood flow in transplanted islets (41); however, since hyperglycemic animals had the most BrdU labeling, this effect is unlikely. Furthermore, the even distribution of BrdUpositive cells throughout the graft suggests that BrdU was accessible to all transplanted tissue. Although a growth limitation due to the heterotopical location of the islets can not be ruled out, in rodents the kidney capsule offers better growth conditions than other common transplantation sites such as liver or spleen (27). In addition, syngeneic islets transplanted under the kidney capsule have a better long-term function than islets transplanted into the portal vein (42). Growth after transplantation has been shown to depend on the genetic background of the recipient but no limitations have been previously described for C57Bl/ 6 mice $(29,43)$. Therefore, with hyperglycemia a limitation for beta cell growth is revealed after an initially increased replication.

There was a continuous decline in beta cell mass of the grafts in chronically hyperglycemic animals in spite of beta cell replication being increased by day 10 . Our results suggest that an increased beta cell destruction was occurring that overcame the beta cell replicative capacity. The apparent discrepancy between beta cell replication and beta cell mass illustrates the need to measure both factors to understand the determinants of beta cell mass in islet transplantation. After $30 \mathrm{~d}$ the beta cell mass was significantly lower and, despite the persistent hyperglycemia, the replication was no longer increased. Since no changes in beta cell size were found in these groups, and since the beta cell replication was comparable to that of the control animals, a significant portion of the fall in beta cell mass must be due to increased cell death. Previous studies have reported that a critical beta cell mass must be transplanted to achieve 
normoglycemia $(13,14)$. In the light of our results that observation can be better understood: when hyperglycemia persists after the transplantation of an insufficient beta cell mass, both limited beta cell replication and accelerated beta cell death are found, leading to a progressive reduction in beta cell mass and failure of the transplant. In contrast, when sufficient beta cell mass is transplanted, a balance among beta cell replication, beta cell hypertrophy, and beta cell death is obtained, and, at least during the first month, beta cell mass is kept reasonably constant. Although no conclusive benefit has been shown, insulin is a standard treatment in the first days after islet transplantation in humans (3-5). Insulin treatment may protect islets from some deleterious effects of hyperglycemia, reducing beta cell loss.

When islets were transplanted into normoglycemic recipients, no changes were found in the replicative rate of either transplanted and endogenous pancreatic beta cells. This finding is in agreement with the normal beta cell replicative rate found in the streptozocin diabetic groups when normoglycemia was completely restored after transplantation (see above). Therefore, our results consistently show a normal beta cell replication in transplanted islets of normoglycemic animals during the first month.

In normal recipients the transplanted beta cell mass was dramatically diminished at days 10 and 30, despite normal replication of beta cells. This reduction was confirmed by a similar decrease in the insulin content of the graft; in fact, the reduction in insulin content was even more severe. An alteration in storage of insulin in transplanted islets, or differences in the efficiency of the insulin extraction from pure isolated islets versus grafted islets could account for the severe reduction in insulin content. Immediately after transplantation these normal recipients had an excess of beta cells, with the transplanted islets in addition to their endogenous pancreatic islets, that theoretically could put them at risk for hypoglycemia. Thus, a reduction in beta cell mass could be a protective response against hypoglycemia. Although some reduction in the beta cell mass of the pancreas might have been expected, we were unable to find any significant changes in pancreatic beta cell mass or insulin content. Perhaps the number of transplanted islets was not sufficient to modify the endogenous beta cell tissue, particularly after the dramatic reduction in transplanted beta cell mass that occurred. The atrophy of the transplanted beta cells $10 \mathrm{~d}$ after transplantation shows that the mechanisms underlying the reduction in beta cell mass are different from those causing the loss of beta cell mass in the chronically hyperglycemic animals. The situation could be similar to the atrophy of endogenous beta cells found in the presence of an insulinoma (44). However, cell atrophy alone could not account for the reduction in beta cell mass, and as there was no apparent fall in replication, increased beta cell death was also possibly occurring. During chronic hyperglycemia beta cell function is abnormal (45) and reduced beta cell mass would result from beta cell injury and death (46), while in a situation of normoglycemia with excessive beta cell mass the reduction would be secondary to beta cell atrophy and to cell death. Atrophied cells could act as a functional reserve for a situation of higher demand, providing an extra source of new beta cells that may be of critical importance in islet transplantation where, in the absence of pancreatic ducts, the only source of new beta cells is replication of the preexisting ones (47). We speculate that the transplantation of an excess of beta cells could provide increased functional reserve and regenerative capacity that could lead to longer lasting normoglycemia and, thus, be of practical value:

In summary, when normoglycemia was maintained after transplantation, the replication of grafted beta cells was similar to that of endogenous pancreatic beta cells; while in a hyperglycemic environment, the replication of transplanted beta cells was initially increased but eventually became limited. Furthermore, the mass of transplanted beta cells was progressively reduced during hyperglycemia without changes in beta cell size suggesting increased beta cell death. In contrast, when a sufficient number of islets was transplanted, beta cell mass remained constant after transplantation. When an excessive number of islets were transplanted into normoglycemic recipients, beta cell size and total beta cell mass were reduced, suggesting that beta cell mass was downregulated to protect from hypoglycemia.

\section{Acknowledgments}

We thank C. J. Cahill, R. S. Schlesinger, and J. Hollister for expert technical assistance.

This work was supported by grants DK-35449 and DK-36836 from the National Institutes of Health and a grant from the Juvenile Diabetes Foundation. E. Montaña is the recipient of a postdoctoral grant from the Ministry of Education and Science of Spain.

\section{References}

1. Kemp, C. B., M. J. Knight, D. W. Scharp, W. F. Ballinger, and P. E. Lacy. 1973. Effect of transplantation site on the results of pancreatic islet isografts in diabetic rats. Diabetologia. 9:486-491.

2. Reckard, C., and C. Barker. 1973. Transplantation of intact pancreatic islets across strong and weak histocompatibility barriers. Transplant. Proc. 5:761-763.

3. Tzakis, A. G., C. Ricordi, R. Alejandro, Y. Zeng, J. Fung, S. Todo, A. J. Demetris, D. H. Mintz, and T. E. Starzl. 1990. Pancreatic islet transplantation after upper abdominal and liver replacement. Lancet. 336:402-406.

4. Scharp, D. W., P. E. Lacy, J. V. Santiago, C. S. McCullough, L. G. Weide P. J. Boyle, L. Falui, P. Marchetti, C. Ricordi, R. L. Gingerich, et al. 1991. Results of our first nine intraportal islet allografts in type 1, insulin-dependent diabetic patients. Transplantation (Baltimore). 51:76-85.

5. Warnock, G. L., N. M. Kneteman, E. Ryan, R. E. A. Seelis, A. Rabinovitch, and R. V. Rajotte. 1991. Normoglycemia after transplantation of freshly isolated and cryopreserved pancreatic islets in type 1 (insulin-dependent) diabetes mellitus. Diabetologia. 34:54-58.

6. Sun, A. M., J. A. Codding, and R. E. Haist. 1974. A study of glucose tolerance and insulin response in partially depancreatized dogs. Diabetes. 23:424-432.

7. Yasugi, H., R. Mizumoto, H. Sakurai, and I. Honjo. 1976. Changes in carbohydrate metabolism and endocrine function of remnant pancreas after major pancreatic resection. Am. J. Surg. 132:577-580.

8. Yellin, A. E., T. R. Vecchione, and A. J. Donovan. 1972. Distal pancreatectomy for pancreatic trauma. Am. J. Surg. 124:135-141.

9. Alejandro, R., R. G. Cutfield, F. L. Shienvold, K. S. Polonsky, J. Noel, L. Olson, J. Dillberger, J. Miller, and D. H. Mintz. 1986. Natural history of intrahepatic canine islet cells autografts. J. Clin. Invest. 78:1339-1348.

10. Andersson, A., H. Borg, A. Hallberg, C. Hellerstrom, S. Sandler, and A. Schnell. 1984. Long term effects of cyclosporin A on cultured mouse pancreatic islets. Diabetologia. 27:66-69.

11. Rosenberg, L., M. Kahlenberg, M. Healey, and D. Tanguay. 1991. Cyclosporin is detrimental to islet procurement from adult pancreatic tissue. Transplant. Proc. 23:767-769.

12. Warnock, G. L., and R. V. Rajotte. 1988. Critical mass of purified islet that induce normoglycemia after implantation into dogs. Diabetes. 37:467-470.

13. Warnock, G. L., K. D. Dabbs, M. G. Evans, M. S. Cattral, N. M. Kneteman, and R. V. Rajotte. 1990. Critical mass of islets that function after implantation in a large mammalian. Horm. Metab. Res. (Suppl. 25):156-161.

14. Kaufman, D. B., P. Morel, M. J. Field, S. R. Munn, and D. E. R. Sutherland. 1990. Importance of implantation site and number of islets transplanted on functional outcome following autotransplantation in a canine model. $\mathrm{Horm}$. Metab. Res. (Suppl. 25):162. 
15. Morel, P., F. C. Goetz, K. Moudri-Munnis, E. Freier, and D. E. R. Sutherland. 1991. Long-term glucose control in patients with pancreatic transplants. Ann. Intern. Med. 115:694-699.

16. Kaufman, D. B., K. F. Platt, F. L. Rabe, D. L. Dunn, F. H. Bach, and D. E. R. Sutherland. 1990. Differential roles of Mac- $1^{+}$cells and CD4 ${ }^{+}$and CD8 ${ }^{+}$ $\mathrm{T}$ lymphocytes in primary nonfunction and classic rejection of islets allografts. $J$. Exp. Med. 172:291-302.

17. Andersson, A. 1983. The influence of hyperglycemia, hyperinsulinemia and genetic background on the fate of intrasplenically implanted mouse islets. Diabetologia. 25:269-279.

18. Tze, W. J., F. C. Wong, and A. J. Tingle. 1976. The use of Hypaque-Ficoll in the isolation of pancreatic islets in rats. Transplantation (Baltimore). 22:201205.

19. DeFazio, A., J. A. Leary, D. W. Heley, and M. H. N. Tattersall. 1987 Immunohistochemical detection of proliferating cells in vivo. J. Histochem. $\mathrm{Cy}$ tochem. 5:571-577.

20. Weibel, E. R. 1979. Point counting methods. In Stereological Methods. Vol. 1. Academic Press Ltd., London. 101-161.

21. Albano, J. D. M., R. P. Ekins, G. Mantz, and R. C. Turner. 1972. A sensitive precise radioimmunoassay of serum insulin relying on charcoal separation of bound and free hormones moieties. Acta Endocrinol. 770:487-509.

22. Dean, P. M. 1972. Ultrastructural morphometry of the pancreatic betacell. Diabetologia. 9:115-119.

23. Sato, T., and L. Herman. 1981. Stereological analysis of normal rabbit pancreatic islets. Am. J. Anat. 161:71-84.

24. Bonner-Weir, S., D. Deery, J. L. Leahy, and G. C. Weir. 1989. Compensatory growth of pancreatic beta-cells in adult rats after short-term glucose infusion. Diabetes. 38:49-53.

25. Andersson, A., U. Eriksson, B. Petersson, L. Reibring, and I. Swenne. 1981. Failure of successful intrasplenic transplantation of islets from lean mice to cure obese-hyperglycemic mice, despite islet growth. Diabetologia. 20:237-241.

26. Swenne, I. 1982. The role of glucose in the in vitro regulation of cell cycle kinetics and proliferation of fetal pancreatic beta-cells. Diabetes. 31:754-760.

27. Mellgren, A., A. H. Landstrom, A. Schnell, and B. Petersson. 1986. The renal subcapsular site offers better growth conditions for transplanted mouse pancreatic islet-cells than the liver or spleen. Diabetologia. 29:670-672.

28. Andersson, A., O. Korsgren, and P. Naeser. 1989. DNA replication in transplanted and endogenous pancreatic islets of obese-hyperglycemic mice at different stages of the syndromes. Metab. Clin. Exp. 38:974-978.

29. Dunger, A., O. Korsgren, and A. Andersson. 1990. DNA replication in mouse pancreatic islets transplanted subcapsulary into the kidney or intraportally into the liver. Influence of unilateral nephrectomy or partial hepatectomy. Trans plantation (Baltimore). 49:686-689.

30. Korsgren, O., L. Jansson, S. Sandler, and A. Andersson. 1990. Hyperglycemia-induced b-cell toxicity. The fate of pancreatic islets transplanted into diabetic mice is dependent on their genetic background. J. Clin. Invest. 86:2161-2168.

31. Swenne, I. 1983. Effects of aging on the regenerative capacity of pancreatic beta-cells of the rat. Diabetes. 32:14-19.
32. Woerner, C. A. 1938. Studies of the islands of Langerhans after continuous injection of dextrose. Anat. Rec. 71:33-57.

33. Borgh, L. A. H., and A. Andersson. 1981. Long term effects of glibenclamide on the insulin production, oxidative metabolism and quantitative ultrastructure of mouse pancreatic islets maintained in tissue culture at different glucose concentrations. Acta Diabetol. Lat. 18:65-83.

34. Brockenbrough, J. S., G. C. Weir, and S. Bonner-Weir. 1988. Discordance of exocrine growth after $90 \%$ pancreatectomy in rats. Diabetes. 37:232-236.

35. Hellerstrom, C., I. Swenne, and A. Andersson. 1988. Islet cell replication in diabetes. In The Pathology of the Endocrine Pancreas in Diabetes. P. J. Le febvre and D. G. Pipeleers, editors. Springer-Verlag, Heidelberg. 141-170.

36. Colton, C. K., and E. S. Avgoustiniatos. 1991. Bioengineering in development of the hybrid artificial pancreas. J. Biomech. Eng. (Trans. ASME). 113:152-170.

37. Swenne, I., and A. Andersson. 1984. Effect of genetic background on the capacity for islet cell replication in mice. Diabetologia. 27:464-467.

38. Menger, M. D., S. Jaeger, P. Walter, G. Feifel, F. Hammersen, and K Messmer. 1988. Angiogenesis and hemodynamics of microvasculature of transplanted islets of Langerhans. Diabetes. 38(Suppl. 1):199-201.

39. Griffith, R. C., D. W. Scharp, B. K. Hartman, W. F. Ballinger, and P. E. Lacy. 1977. A morphologic study of intrahepatic portal-vein isograft. Diabetes. 26:201-204.

40. Stagner, J. I., and E. Samols. 1990. The induction of capillary bed development by endothelial cell growth factor before islet transplantation may prevent islet ischemia. Transplant. Proc. 22:824-828.

41. Sandler, S., and L. Jansson. 1987. Flow measurements in transplanted pancreatic islets of the rat. J. Clin. Invest. 80:17-21.

42. Hiller, W. F. A., J. Klempnauer, R. Luck, and B. Steiniger. 1991. Progressive deterioration of endocrine function after intraportal but not kidney subcapsular rat islet transplantation. Diabetes. 40:134-140.

43. Korsgren, O., L. Jansson, and A. Andersson. 1989. Effects of hyperglycemia on function of isolated mouse pancreatic islets transplanted under kidney capsule. Diabetes. 38:510-515.

44. Appel, M. C., D. Simon, W. L. Chick, E. S. Werringer, and A. A. Like 1980. Recovery of suppressed islets after removal of a transplantable insulinoma. Diabetologia. 19:253. (Abstr.)

45. Leahy, J. L., H. E. Cooper, D. A. Deal, and G. C. Weir. 1986. Chronic hyperglycemia is associated with impaired glucose influence on insulin secretion a study in normal rats using chronic in vivo glucose infusions. J. Clin. Invest. 77:908-915

46. Imamuira, T., M. Koffler, J. H. Helderman, D. Prince, R. Thirlby, A. L. Inman, and R. H. Unger. 1988. Severe diabetes induced in subtotally depancreatized dogs by sustained hyperglycemia. Diabetes. 37:600-609.

47. Bonner-Weir, S. 1992. Two pathways of beta-cell growth in the regenerating rat pancreas: implications for islet transplantation. Diabetes Nutr. Metab. 5(Suppl. 1):21-24. 